\title{
PRAKTIKUM REKRUTMEN PENDONOR SECARA TATAP MUKA DAN ONLINE DI PRODI D3 TEKNOLOGI BANK DARAH SURAKARTA
}

\author{
Results analysis of practicum of recruitment of donors based on advance and \\ online learning in D3 Study Program Of Bank Darah Surakarta
}

\author{
Danik Riawati ${ }^{1}$, Budi Purwanto ${ }^{2}$, Riki Mirzam Abdurrozaq ${ }^{3}$ \\ ${ }^{1}$ Politeknik Akbara Surakarta, \\ ${ }^{2}$ Politeknik Akbara Surakarta, \\ ${ }^{3}$ PMI Kota Surakarta, \\ riawatidanik81@gmail.com
}

\begin{abstract}
ABSTRAK
Latar belakang: Pendidikan sangat penting bagi kita terutama bagi generasi penerus bangsa supaya dapat menciptakan sumber daya manusia yang berkualitas untuk masa depan bangsa dan negara.

Tujuan: untuk menganalisis hasil pembelajaran praktikum rekrutmen pendonor secara tatap muka dan online di Prodi D3 Teknologi Bank Darah Surakarta.

Metode: Penelitian ini merupakan penelitian deskriftif dengan rancangan penelitian cross sectional. Populasi: semua mahasiswa yang mendapatkan mata kuliah Rekrutmen Pendonor pada semester genap TA 2019/2020. Subyek penelitian ini semua mahasiswa tingkat IIB Politeknik Akbara Surakarta yaitu sebanyak 30 orang. Teknik pengambilan sampel menggunakan total sampling. Metode pengumpulan data menggunakan data sekunder. alat pengumpulan data berupa daftar nilai pada semester genap 2019/2020. Teknik pengolahan data menggunakan editing, koding, tabulating dan entering. Analisa univariat disajikan dalam bentuk tabel distribusi frekuensi dan analisa bivariat menggunakan uji korelasi spearman dengan bantuan program SPSS versi 26.

Hasil: Nilai signifikansi sebesar 0,048<0,05 maka signifikan. analisa data menggunakan analisa univariat yang disajikan tabel distribusi frekuensi dan analisa bivariat menggunakan uji korelasi spearman. Nilai koefisien korelasi spearman yaitu sebesar 0,364 artinya cukup kuat. Arah korelasi dilihat dari angka koefisien korelasi hasilnya positif sehingga hubungan antara kedua variabel searah.

Simpulan: Nilai koefisien korelasi spearman yaitu sebesar 0,364 artinya hubungan antar kedua variabel cukup kuat dan signifikan serta arah korelasi kedua variabel searah.
\end{abstract}

Kata kunci: Praktikum; tatap muka; online; 


\begin{abstract}
Background: Education is very important for us, especially for the nation's future generations in order to create quality human resources for the future of the nation and state

Purpose: to analyze the learning outcomes of face-to-face and online donor recruitment practicum in Surakarta Blood Bank Technology D3 Study Program.

Methods: This research is a descriptive study with a cross sectional study design. Population: all students who received the Donor Recruitment course in the even semester of the 2019/2020 academic year.

.Result: The significance value is $0.048<0.05$, it is significant. Data analysis used univariate analysis which presented frequency distribution tables and bivariate analysis was tested with Spearman's rho correlation test. The spearman correlation coefficient value is 0.364 which means it is quite strong. The direction of the correlation seen from the correlation coefficient is positive so that the relationship between the two variables is unidirectional.

Conclusion: The spearman correlation coefficient value is 0.364 , which means that the relationship between the two variables is strong and significant and the correlation between the two variables is unidirectional. The subjects of this study were all students at the level IIB of Surakarta Akbara Polytechnic, as many as 30 people. The sampling technique used total sampling. The sampling technique used total sampling. The data collection method uses secondary data. data collection tool in the form of a list of scores in the even semester 2019/2020. Data processing techniques use editing, coding, tabulating and entering. Univariate analysis is presented in the form of a frequency distribution table and bivariate analysis using the Spearman correlation test with the help of the SPSS version 26 program.

Result: The significance value is $0.048<0.05$, it is significant. Data analysis using univariate analysis presented frequency distribution tables and bivariate analysis using the Spearman correlation test. The spearman correlation coefficient value is 0.364 which means it is quite strong. The direction of the correlation seen from the correlation coefficient is positive so that the relationship between the two variables is unidirectional.

Conclusion: The value of the Spearman correlation coefficient is 0.364 which means that the relationship between the two variables is quite strong and significant and the correlation direction of the two variables is unidirectional.
\end{abstract}

Keywords: Practicum learning; face to face; on line;

\title{
PENDAHULUAN
}

Pendidikan merupakan kunci tumbuh kembang bagi generasi penerus bangsa sehingga dapat menciptakan sumber daya manusia yang berkualitas (Kemendikbud, 2020). Hal ini dikarenakan dalam pendidikan diperlukan proses pembelajaran yang dapat merangsang keingintahuan seseorang, sehingga dapat 
mendorong untuk melakukan langkah-langkah dalam mencari fakta (Mujiman $\mathrm{H}$, 2011). Contohnya pendidikan pada program studi D3 Teknologi Bank Darah mempelajari tentang rekrutmen pendonordengan harapan lulusannya mampu bertindak sebagai edukator layanan darah yaitu teknisi yang memberikan komunikasi, informasi, edukasi di bidang pelayanan darah (Kemenkes RI, 2018). Pembelajaran dapat dilakukan dengan berbagai metode dengan harapan kegiatan proses belajar mengajar tetap dapat berjalan.

Negara Indonesia saat ini berada pada posisi darurat COVID-19, sehingga dapat mempengaruhi di semua bidang seperti pembelajaran, pekerjaan dan sebagainya. Salah satunya contohnya dampak pembelajaran tidak dapat di lakukan secara tatap muka, karena untuk mencegah penyebaran virus. Berdasarkan hal tersebut, maka diperlukan upaya untuk mengatasinya. Beberapa upaya seperti kebijakan dalam melaksakan pekerjaan, beribadah dan belajar. Contohnya pembelajaran tatap muka diubah menjadi pembelajaran daring/online dapat dilakukan dari rumah. Upaya ini mempunyai tujuan untuk menekan angka penyebarannya Covid 19.

Tindakan pembelajaran secara daring/online membuat semua orang untuk saling membantu dan mendukung dalam proses penyampaian materi. Hal ini mengalami perubahan yang sangat besar dan ada beberapa hal yang terkendala karena pembelajaran harus dilakukan secara tatap muka, seperti sinyal, pembelajaran pratikum dan sebagainya. misalnya proses pembelajaran rekrutmen pendonor diberikan dengan tujuan untuk diberikan dengan tujuan untuk mendapatkan lulusannya yang mampu bertindak sebagai edukator layanan darah yaitu teknisi yang memberikan komunikasi, informasi, edukasi di bidang pelayanan darah (Kemenkes RI, 2018). Matakuliah ini ada teori dan praktikum, adapun praktikum rekrutmen pendonor seperti sosialisasi dan kampanye donor darah suka rela, pengarahan donor dan pelestarian donor (Kemenkes, 2015).

Beberapa penelitian terdahulu saat pembelajaran tatap muka sebelum masa pandemi covid-19 yaitu menurut Riawati D tahun 2020 meyimpulkan bahwa ada hubungan yang berarti antara nilai praktikum edukator pelayanan darah dengan nilai UAS KIE dan Promosi Kesehatan. Menurut Lieskusumastuti A. D dan Riawati tahun 2018, menyatakan bahwa ada hubungan signifikan antara keaktifan praktikum dengan hasil evaluasi ujian ANC pada mahasiswa Prodi DIII Kebidanan STIKES Mamba'ul 'Ulum Surakarta.

Penelitian terdahulu tentang pembelajaran daring menurut Hikmat dkk tahun 2020 menyimpulkan bahwa belajar secara daring dengan zoom dan whatsApp hanya efektif bagi mahasiswa teori dan teori dan teori dan praktikum, sedangkan pada matakuliah praktik dan mata kuliah lapangan, perkuliahan secara onlie kurang efektif.

Berdasarkan urian diatas maka penulis tertarik mengambil judul penelitian" Praktikum Rekrutmen Pendonor Secara Tatap Muka dan Online Pada Mahasiswa Prodi D3 Teknologi Bank Darah Surakarta”.

Penelitian ini mempunyai tujuan untuk menganalisis hasil pembelajaran praktikum rekrutmen pendonor secara tatap muka dan online di prodi D3 Teknologi Bank Darah Surakarta. 


\section{METODE}

Penelitian ini merupakan penelitian deskriftif dengan rancangan penelitian cross sectional. Populasi: semua mahasiswa yang mendapatkan mata kuliah Rekrutmen Pendonor pada semester genap TA 2019/2020. Subyek penelitian ini semua mahasiswa tingkat IIB Politeknik Akbara Surakarta yaitu sebanyak 30 orang. Teknik pengambilan sampel menggunakan total sampling. Metode pengumpulan data menggunakan data sekunder. Alat pengumpulan data berupa daftar nilai pada semester genap 2019/2020 dengan pelaksanaan pratikum rekrutmen pendonor berpedoman pada Peraturan Menteri Kesehatan Republik Indonesia No. 91 Tahun 2015 Tentang Standart Pelayanan Tranfusi Darah. Teknik pengolahan data menggunakan editing, koding, tabulating dan entering. Analisa univariat disajikan dalam bentuk tabel distribusi frekuensi dan analisa bivariat menggunakan uji korelasi spearman dengan bantuan program SPSS versi 26.

\section{HASIL DAN PEMBAHASAN}

\section{Hasil}

Tabel 1 Distribusi frekuensi nilai pratikum Rekrutmen pendonor dengan metode pembelajaran tatap muka

\begin{tabular}{clc|c}
\hline & & Frequency & Percent \\
\hline Valid & $<70$ & 1 & 3.3 \\
& $70-79,9$ & 12 & 40.0 \\
& $>79,9$ & 17 & 56.7 \\
& Total & 30 & 100 \\
\hline
\end{tabular}

Sumber data primer, September 2020

Berdasarkan tabel 1 didapatkan bahwa nilai praktikum rekrutmen pendonor secara tatap muka mendapatkan nilai tertinggi pada rentang $>79,9$ sebanyak 17 responden $(56,7 \%)$ dan yang terkecil pada rentang $<70$ sebanyak 1 orang $(3,3 \%)$.

Tabel 2 Distribusi frekuensi nilai pratikum Rekrutmen pendonor dengan metode pembelajaran during

\begin{tabular}{llcc}
\hline & & Frequency & Percent \\
\hline Valid & $<70$ & 0 & 0 \\
& $70-79,9$ & 16 & 53.3 \\
& $>79,9$ & 14 & 46.7 \\
& Total & 30 & 100 \\
\hline
\end{tabular}

Sumber data primer, September 2020

Berdasarkan tabel 2 didapatkan bahwa nilai praktikum rekrutmen pendonor secara tatap online yang mendapatkan nilai tertinggi pada rentang 70-79,9 sebanyak 16 responden $(56,7 \%)$ dan yang terkecil pada rentang $<70$ tidak ada. 
Tabel 3 Analisa bivariat nilai pratikum Rekrutmen pendonor dengan metode pembelajaran tatap muka dan daring/online menggunakan uji korelasi spearman

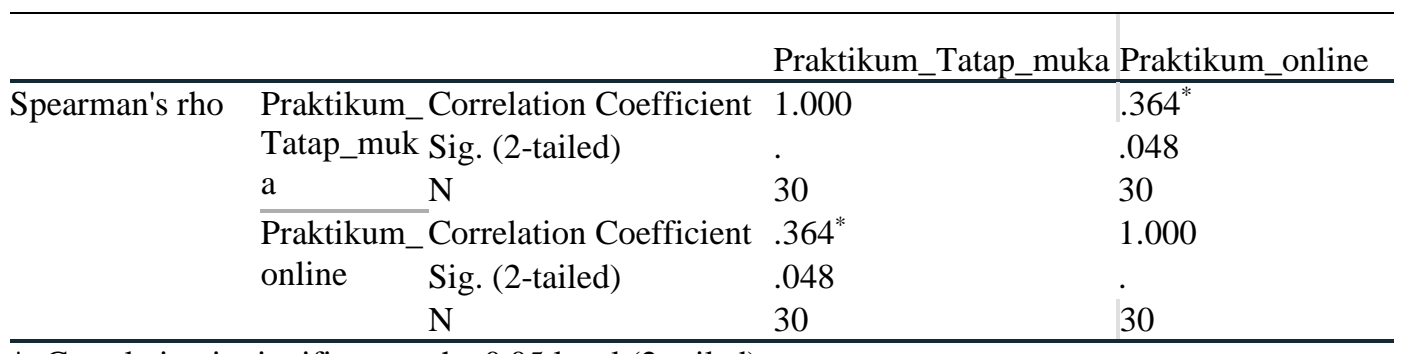

*. Correlation is significant at the 0.05 level (2-tailed).

Berdasarkan tabel 3 didapatkan bahwa nilai koefisien korelasi spearman yaitu sebesar 0,364 artiny cukup kuat. Hubungan kedua variabel signifikan karena nilai signifikansi $0,048<0,05$. Arah korelasi dilihat dari angka koefisien korelasi hasilnya positif sehingga hubungan antara kedua variabel searah.

\section{Pembahasan.}

Tabel 1 didapatkan bahwa nilai praktikum rekrutmen pendonor secara tatap muka mendapatkan nilai tertinggi pada rentang $>79,9$ sebanyak 17 responden $(56,7 \%)$. Hal ini sesuai dengan teori evaluasi hasil belajar peserta didik adalah penilaian yang dilakukan terhadap hasil proses belajar peserta didik dalam bentuk tatap muka dan jarak jauh berbasis TIK (Kemndikbud, 2014). Hal ini didukung oleh Riawati D tahun 2020 evaluasi pembelajaran praktikum secara tatap muka sebelum masa pandemi covid-19 menyimpulkan bahwa ada hubungan yang berarti antara nilai praktikum edukator pelayanan darah dengan nilai UAS KIE dan Promosi Kesehatan. Penelitian sejenis menurut Lieskusumastuti A. D dan Riawati tahun 2018, menyatakan bahwa ada hubungan signifikan antara keaktifan praktikum dengan hasil evaluasi ujian ANC pada mahasiswa Prodi DIII Kebidanan STIKES Mamba'ul 'Ulum Surakarta.

Tabel 2 didapatkan bahwa nilai praktikum rekrutmen pendonor secara tatap online yang mendapatkan nilai tertinggi pada rentang 70-79,9 sebanyak 16 responden $(56,7 \%)$. Menurut teori praktikum adalah tugas terstruktur dan berhubungan dengan validasi fakta atau hubungan antara fakta, yang mendukung capaian pembelajaran (learning outcomes) secara utuh sesuai dengan yang di syaratkan dalam kurikulum (Kemendikbud, 2014).

Berdasarkan tabel 1 dan 2 didapatkan nilai praktikum rekrutmen pendonor yang seimbang yaitu nilai tertinggi pada rentang 70-79,9 (56,7\%) secara tatap muka maupun online. Menurut teori proses pembelajaran yang dapat merangsang keingintahuan seseorang, sehingga dapat mendorong untuk melakukan langkahlangkah dalam mencari fakta (Mujiman H, 2011). Hal ini dikarenakan keaktifan belajar mahasiswa walaupun dalam kondisi pandemi covid-19.

Tabel 3 didapatkan bahwa nilai koefisien korelasi spearman yaitu sebesar 0,364 artinya cukup kuat. Hubungan kedua variabel signifikan karena nilai 
signifikansi $0,048<0,05$. Arah korelasi dilihat dari angka koefisien korelasi hasilnya positif sehingga hubungan antara kedua variabel searah. Hal ini sesuai dengan teori e-learning merupakan proses belajar dan pembelajaran yang memanfaatkan informasi elektronik dengan tujuan untuk kepentingan pembelajaran dan pendidikan, yang di akses oleh peserta didik, dimana saja dan kapan saja berbasis TIK (Kemendikbud, 2014). Penelitian ini bertentangan dengan penelitian Hikmat dkk tahun 2020 menyimpulkan bahwa belajar secara daring dengan zoom dan whatsApp hanya efektif bagi mahasiswa teori dan teori dan teori dan praktikum, sedangkan pada matakuliah praktik dan mata kuliah lapangan, perkuliahan secara onlie kurang efektif.

\section{SIMPULAN DAN SARAN}

\section{Simpulan}

Nilai koefisien korelasi spearman yaitu sebesar 0,364 artinya cukup kuat. Hubungan kedua variabel signifikan karena nilai signifikansi $0,048<0,05$. Arah korelasi dilihat dari angka koefisien korelasi hasilnya positif sehingga hubungan antara kedua variabel searah.

\section{Saran}

Bagi peneliti selanjutnya diharapkan meneliti faktor-faktor yang mempengaruhi sistem pembelajaran tatap muka maupun online. Bagi institusi perlu adanya kolaborasi pembelajaran sehingga ada pemebelajaran yang dapat dilakukan tatap muka maupun online.

\section{DAFTAR PUSTAKA}

Riawati D, 2020. Analisis Nilai Praktikum Edukator Pelayanan Darah Terhadap Nilai Ujian Akhir (UAS) Komunikasi Informasi Edukasi (KIE) Dan Promosi

Kesehatan. Journal of Health Research Avicenna Volume 3 Nomor 1 Bulan $\begin{array}{llll}\text { Maret } 2020 . & \text { Hal: } & \text { 72-79. }\end{array}$ https://jurnal.stikesmus.ac.id/index.php/avicenna/article/view/344. 27 Agustus 2020, Jam: 08.00 WIB.

Hikmat dkk, 2020. Efektifitas Pembelajaran Daring Selama Masa Pandemi Covid-19: sebuah survey online. http://digilib.uinsgd.ac.id/30625/1/FISIP\%20Kelompok\%207.pdf. Karya Tulis Ilmiah (KTI) Masa Work From Home (WFH) Covid-19 UIN Sunan Gunung Djati Bandung Tahun 2020. 27 Agustus 2020, Jam: 08.00 WIB.

Kemenkes RI, 2018. Kurikulum inti pendidikan diploa III teknologi bank darah. Jakarta: Kemenkes RI BPSDM PPSDMK.

Kemendikbud, 2014. Panduan Penjaminan Mutu Sistem Pembelajaran Daring Indonesia Terbuka dan Tertutup. Jakarta: Direktorat Pembelajaran dan Kemahasiswaan Direktorat Jendrat Pendidikan Tinggi Kementerian Pendidikan dan Kebudayaan. 
Kemendikbud, 2020. Surat Edaran No.2 Tahun 2020 Tentang Pencegahan Dan Penanganan Corona Virus Disease (Covid-19). Jakarta: Keenterian Pendidikan Dan Kebudayaan . http://pgdikmen.kemdikbud.go.id/readnews/surat-edaran-mendikbud-nomor-2-tahun-2020.

Lieskusumastuti A dan Riawati D, 2018. Hubungan Keaktifan Praktikum dengan hasil Evaluasi Ujian Antenatal care pada mahasiswa prodi DIII kebidanan STIKES Mamba'ul 'Ulum Surakarta. Journal of Health Research Avicenna Volume 1 Nomor 1 Bulan Maret 2018. Hal: 73-81. https://jurnal.stikesmus.ac.id/index.php/avicenna/article/view/198. Diakses tanggal 27 Agustus 2020, Jam: 08.00 WIB.

Mudjiman, 2011. Belajar Mandiri Pembekalan Dan Penerapan. Surakarta: UPT. Penerbit dan Percetakan UNS (UNS Press)

Menkes RI, 2015. Peraturan Menteri Kesehatan Republik Indonesia No. 91 Tahun 2015 Tentang Standart Pelayanan Tranfusi Darah. http://www.hukor.kemkes.go.id/uploads/produk_hukum/PMK_No.991_ttg Standar_Transfusi_Pelayanan_Darah_pdf. 27 Agustus 2020, Jam: 08.00 WIB. 